\title{
Risk Aversion, Efficient Markets and the Forward Exchange Rate
}

\author{
Kees G. Koedijk and Mack Ott
}

$\mathbf{R}$ avoid it explain such arrangements as insurance, limited liability firms and diversification of investment portfolios. In recent years, risk aversion and the attendant premium for risk-bearing have been used increasingly to explain a stubborn paradox in the empirical exchange rate literature: the failure of the forward exchange rate to be an unbiased predictor of the future spot exchange rate.

In this article, we review recent economic analyses of the risk premium's role in foreign exchange markets. The starting point is an explanation of covered and uncovered interest parity and their relation to the risk premium. We then furn to a discussion of empirical tests of efficiency. In particular, we examine two recent papers that demonstrate the existence of the risk premium but differ in their conclusions about market effciency: Fama (1984) and Frankel and Froot (1986).

\section{COVERED AND UNCOVERED INTEREST PARITY}

Currencies are exchanged spot and forward in highly organized markets. The high volume of trade by

Mack Ott is a senior economist at the Federal Reserve Bank of St. Louis. Kees $\mathrm{G}$. Koedijk is an assistant professor of economics at Erasmus University, Rotterdam, the Netherlands. James C. Poletti and Nancy D. Juen provided research assistance. competitive, well-informed individuals suggests that the foreign exchange market fits Fama's (1970) definition of an efficient market: "A market in which prices always 'fully reflect' available information." An analysis of forward exchange market efficiency and the risk premium draws on market information as revealed by relations between interest differentials and exchange rates. These relations are called the covered and uncovered interest parity conditions.

Covered interest parify (CIP) relates the forward premium $\left(\mathrm{F}_{\mathrm{t}}-\mathrm{S}_{\mathrm{t}}\right)$ to the interest differential,

$$
\text { (1) } \mathrm{i}-\mathrm{i}^{*}=\left(\mathrm{F}_{\mathrm{t}}-\mathrm{S}_{1}\right) \alpha
$$

where

$$
\begin{aligned}
& \mathrm{i}=\log \text { of } 1 \text { plus U.S. three-month T-bill interest } \\
& \mathrm{i}^{*}=\log \text { of } 1 \text { plus foreign equivalent of T-bill } \\
& F_{1}=\log \text { of the forward exchange rate dollars } \\
& \text { per foreign curvency unit) } \\
& \mathrm{S}_{\mathrm{t}} \quad=\log \text { of the spot exchange rate dollars } \\
& \text { per foreign currency unit), } \\
& \alpha=\text { annualizing factor - } 12 \text { divided by number of }
\end{aligned}
$$

The right-hand side of (1), which is the annualized forward premium on foreign currency, measures the rate of return in domestic carrency on a covered 
exchange position - that is, a spot purchase of foreign cutrency offset by a forward sale, The equality with the differential between the domestic and foreign interest rate on the left-hand side is brought about by arbim trage: since the bonds are assumed to be default free in their respective currencies, a riskless excess retum would be available if CIP did not hold.'

Because the forward rate is the present contractual dollar price of foreign currency for future delivery, the assumptions of market efficiency and no risk pre. mium imply a second form of interest parity called uncovered interest parity (UIP). An expression for ULP can be obtained from the arbitrage condition which equates the expected change in the spot rate plus the premium for risk with the forward premium:

$$
E_{1}\left[S_{1}\right]-S_{1}+P_{:}=F_{1}-S_{1}
$$

where

$$
\begin{aligned}
& E_{1}\left[S_{1+1}\right]= \text { the expectation of the period- }+k \\
& \text { spot rate based on period-t informa- } \\
& \text { tion, } \\
& P_{1}=\text { the risk premium for bearing the uncer- } \\
& \text { tainty of unexpected curency price } \\
& \text { changes. }
\end{aligned}
$$

Under the no-risk-premium hypothesis,

(3) $\quad \mathrm{P}_{1}=0$,

then, from $(1)$, we have the second form of interest parity, LIP:

(4) $\quad \mathrm{i}-\mathrm{i}^{*}=\left[\mathbb{E}_{i}\left[S_{1 \cdots h}\right]-S_{1}\right) \alpha$.

Comparing equation 4 with equation 1 , Ue implies that the forward rate, $F_{1}$, which is observable to the market at timet, is equal to the market's forecast of the future spot exchange rate at time $t+k$. Note that uncovered interest parity is conditional upon the hypothesis of no risk preminm; only if (3) holds will the annualized rate of the expected change in spot rate be equal to the cment interest differential.

The risk premium, $P_{1}$, on buying a currency in the forwand market is implicitly detined by equation 2 . That is, individuals who do not want to bear the uncertainty of holding an open curency position buy foward currency to hedge this risk. As shown in the lefthand side of equation 2 , the price these hedgers pay includes the risk premium, the price of insuring against this uncertainty. It is the difference between

\footnotetext{
CIP has been supported in a variely of empirical investigations; see
} Cinton ( 1987 ) and Isard 1987, pp. $7-8$. the log of the forward rate and the log of the expected, but unobservable, future spot rate,

$$
\text { (5) } \quad P_{1}=F_{1}-E\left[S_{1}\right] \text {. }
$$

For instance, if the risk premium is positive, speculators sell foreign currency forward at price $F$, and expect to be able to buy the foreign currency spot at time $t+k$ for $E_{1}\left(S_{1, h}\right.$, profiting by doing so at rate $P_{1}$ annual ate $\alpha P_{1}$ ). Note that, if the risk premium is not zero, the matket actually can expect the dollar to depreciate, even though the observed interest differential and the forward premium indicate an appreciation of the dollar:"

\section{Risk Premium or Market Inefficiency}

Current investigations of the relationship between the spot and forward exchange rates are premised on a widely documented finding: the simple no-riskpremium efficiency criterion, defined jointly by equations 2 and 3 , has been refuted by many empirical studies. Using a variety of assumptions, data, time periods and estimation techniques, investigators have established three fundamental points: ${ }^{3}$

1) The forward exchange rate is not an unbiased predictor of the future spot rate.

2) The residuals obtained in a regression of spot exchange rates of their lagged forward rates hequently exhibit serial comelation

3 There exist systems filters that permit profitable speculation in foreign exchange either through the purchase of foreign assets with offseting forward exchange sales or buy and hold strategies.

${ }^{2}$ An example may clarify this relation among the premium, forward rate and expected future spot rate. Suppose the dolar-DM spot exchange rate is $\$ .5512 \mathrm{DM}$, the three-month forward rate is \$.5494/DM, and the expected future spot rate three months hence is \$.5556/DM. Since the risk premium is negative, the speculative position will be against the dollar rather than against the DM. The speculator (whose beliefs are represented by the expected future spot rate) would expect to make a profit by selling dollars forward and buying DM assets. After holding the DM assets for three months, the speculator anticipates seling the DM assets and using the proceeds to buy dollars. The speculative rate of profit - that is, the excess over a hedged, secure return - anticipated over the three months is, from equation $2,1.12$ percent or 4.49 percent on an anrual basis:

$$
\begin{aligned}
-P_{1} & =\left\{\left[E_{i}\left(S_{t: 3}\right)-S_{t}\right]-\left[F_{t}-S_{t}\right]\right]^{*} 4 \\
& =\{[\ln (.5556)-\ln (.5512)]-[\ln (.5494)-\ln (.5512)]\}^{*} 4 \\
& =.0449
\end{aligned}
$$

These characteristics have been widely discussed. For the biasedness of forward rates, see Robichek and Eaker (1978), Levich (1979), Cumby and Obstfeld (1981), Hansen and Hodrick (1980) and Meese and Rogoff (1983). The serial corretation of errors has been noted by Hansen and Hodrick (1980) and Cumby and Obstfeld (1984). On the existence of profitable speculation through "fitters" (obtained from lagged data) see Levich (1979), Bilson (1981) and Sweeney (1986) 
Given the ample empirical evidence, most researchers accept the rejection of the simple no-risk-premium efficiency criterion; however, they remain divided on whether the existence of a risk premium or market inefficiency is responsible for this result.

Why has it been so difficult to test for the presence of a risk premium? The answer is that while, in general, we do not have actual $e x$ ante expectations data, we assume that foreign exchange market participants are rational in their decisions, including their pricing of risk. Hence, the expectation of the future spot rate is equal to its actual, subsequently observed value plus a random error and, perhaps, a risk premium. Consequently, whenever the observable value of $F_{t}-S_{t+k}$ is different from zero, there is ex post evidence on the existence of a risk premium or market inefficiency or both, but no direct evidence bearing on which. ${ }^{*}$

The empirical difficulties in assessing the presence of a risk premium from simple calculations of $F_{-}-S_{1 \neq 1}$ can be gathered from chart 1. In this chart, we have plotted the so-called ex post or rational expectations risk premium, $\mathrm{F}_{1}-\mathrm{S}_{1+1}$ (annualized), for the dollar/ deutsche mark exchange rate from January 1976 through June 1985. As is evident, it is difficult to show that the forward rate systematically underpredicts or overpredicts the future spot rate. When long periods of time are considered, the average prediction error of the forward exchange rate is close to zero. Fortunately, however, two direct tests for the presence of a risk prenitum in the foreign exchange market have emerged from the literature.

\section{TWO TESTS OF EFFICIENCY AND RISK PREMIA}

Recently, two studies of exchange rates have offered tests that separate the rational expectations hypothesis and the existence of a risk premium. These papers use different methods, time periods and data sets, and they arrive at different conclusions about the relative importance of the risk premium and expectation errors.

\footnotetext{
${ }^{4}$ Of course, this is conditional on expectations being rationally formed. Even so, unforeseen events transpiring between time $t$ and $t+k$ may result in $F_{t}-S_{.} \neq 0$. Such unforeseen events, dubbed "news" by Frenkel (1981) explains some variation in $F_{1}-S_{1+k}$ due neither to a risk premium nor nonfational expectations; however. news should not resulf in biased expectations since unforeseen events must have an expected mean of zero.
}

The first paper is Fama's (1984) article, which assesses the relative variability of the risk premium and forecast errors during 1973-82. Fama concludes that the risk premium explains more of the variance than the forecast error does. Furthermore, he also finds that the risk premium and the expected (but unobserved) future spot rates are negatively correlated.

The second paper, Frankel and Froot (1986), uses the median response from survey data of foreign exchange traders' expectations of future spot rates." Their study, primarily covering 1981-85, finds a risk premium varying between 3 percent and 10 percent depending on the currency observed. Thus, they are able to test directly the rational expectations hypothesis and to estimate the proportion of the forward rate error that can be ascribed to forecast error and to risk premia.

Their findings concur with Fama's in two respects - the risk premium is significant and negatively correlated with the expected future spot rate - but diverge in terms of the relative variances of forecast errors and risk premia:

In all three surveys, the errors exhibit unconditional bias of a sign opposite to estimates of the lisk premium from the survey data. The premia are large in absolute value, and are statistically different from zero. We can reject the hypothesis that systematic unconditional mistakes made by the forward rate in predicting the future spot rate are due entirely to a falume of rational expectations. But at the other extreme, the hypothesis that the forward rate prediction errors can be explained by the risk premium alone is also rejected. Expected depreciation is more variable than both the forward discount and the risk premium. The first finding corroborates Fama's (1984) conjecture that expected depreciation and the risk premium are negam tively correlated. The second finding rejects the hypothesis that the variance of expected depreciation is less than the variance of risk premium ...."

\footnotetext{
5Frankel and Froot used three different surveys: Money Market Services (MMS), Inc, biweekly January 1983-October 1984 , weekly 1984-86, polted an average of 30 currency traders or economists at major international banks; The Economist Financial Report every six weeks June 1981-December 1985 conducted telephone interviews with currency traders at 14 leading international banks; finally, Amex Bank Review 1976-85 annually Surveyed 250-300 central and private bankers, corporate officers and economists. In each case, respondents were asked for exchange rate forecasts at various horizons for the pound, mark, Swiss franc, yen and (except for MMS) French franc. Details of these surveys can be found in the data appendix of Frankel and Froot (1987), p. 151

${ }^{6}$ Frankel and Froot (1986), p. 29. Originally, this negative corretation was presented by Fama (1984) as a puzzle; however, as shown in Hodrick and Srivastava (1986), it is perfectly consistent with the intertemporal asset pricing model of forward exchange markets.
} 
Chart 1

The Ex Post Risk Premium $\longleftarrow$

Dollars per Deutsche Mark

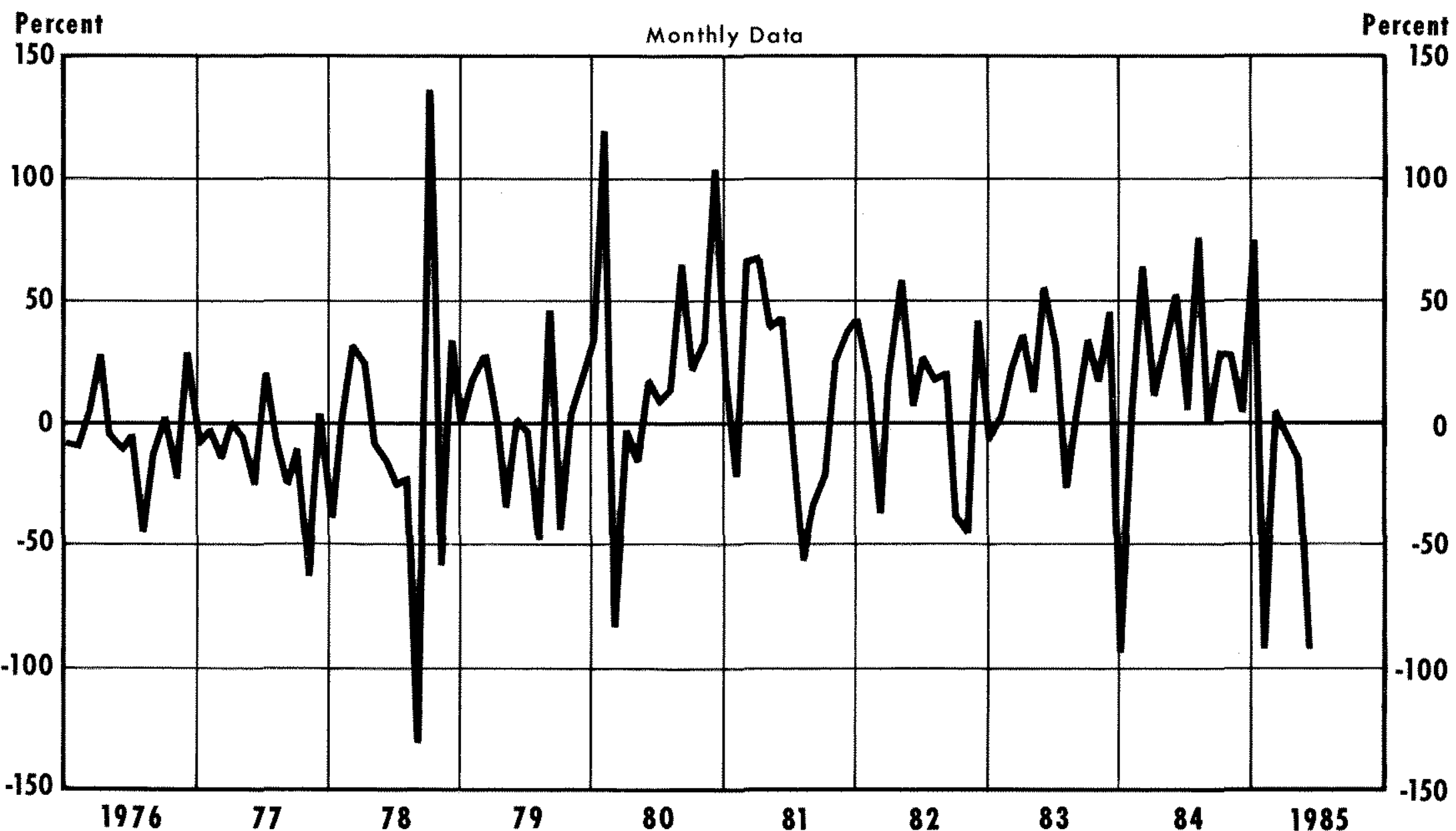

11 The annualized difference between the log of the forward rate and the $\log$ of a one-month lead of the observed spot rate. 


\section{Assessing the Divergent Findings of Fama and Frankel-Froot}

The two papers, which use very different methodologies, concur in the statistical significance of a risk premium, but are in dispute about its economic significance. On the one hand, Fama's paper, as well as others whose research has followed his lead, asserts that the risk premium accounts for most of the forward rate error. An implication is that the efficiency of forward exchange markets is not refuted. A corollary of this implication is that, since foreign exchange trading is not subject to biased forecasts, policy intervention in foreign exchange markets cannot be justiffed on the existence of destabilizing and misguided speculation.

In contrast, the findings of Frankel and Froot assert that, although the risk premium is statistically significant, it is smaller (in absolute value and varability) than the forward rate forecast errors made by the surveyed traders, economists and corporate officers of international banks. Moreover, they find that the expectations of these surveyed traders are systematically biased, that their speculative activity is excessive and that the risk premitum is without economic significance:

The data continue to rejed statistically the hypothesis of rational expectations ... in favor of the alternative of axcessive speculation... Put diffetently, even after allowing for moastrement error, it is still not possible to wect the hypothesis that all the bias consists of repeated expectational crrors made by survey respondents, and that no positive portion of the bias can be atfributed to the survev risk premium."

These disparate findings require some resolution. Besides the different statistical methodologies used, there are two fundamental differences between their analyses. First, the two papers use different data sets for their empirical tests: Fama's study covers data observed at four-week intervals from August 1973 through December 1982, while Frankel-Froot's data are of varying frequency over primarily 1981-85." Fama's sample covers nine exchange rates, including the six that Frankel-Froot examine. Second, the FrankelFroot study uses survey data rather than the ex post market observations for the expectation proxy. This

'For example, see Hodrick and Srivastava (1986). Frenkel (1986) and Boothe and Longworth (1986).

${ }^{8}$ Frankel and Froot (1986), p. 28, emphasis added.

${ }^{9}$ Frankel-Froot do report some earlier data (1976-78), but the bulk of their tests are on data from the 1980 s. creates some problems of interpretation, as FrankelFroot recognize ${ }^{10}$ While the measurement errors can be statistically addressed, there are three economic differences between survey opinion and market actions that warrant consideration in weighing the conflicting results of Fama and Frankel and Froot.

Survey responses may deviate from market expectations first because a single observation rather than a weighted average forms the datum, That is, FrankelFroot use the median response to represent the typical market agent. In contrast, when expectations are deduced from market actions (actual portfolio positions or changes in position), the expectations of every active agent are included in a composite average with the weights being asset holdings or changes in asset holdings. This population-weighted, distributionbased expectation may differ considerably from the median proxy, especially if the tails of the expectation distribution contain the beliefs of the agents making the largest purchases. If differences of opinions as well as changes in information move markets, then median survey responses will offer incomplete guides to market expectations.

A related, but slightly different aspect of the difference between survey and market data is that the latter is substantiated by action. Surveys are frequently misleading in that agents are not disciplined in their responses by having to take positions that risk wealth. put differently, actions speak louder than words, or talk is cheap.

Finally, the survey responses may not be expected values but rather modal values - the most likely values - or, perhaps, risk-adjusted expectations. For example, Frankel-Froot (1986) describe each of their three data sets in about the same form as the Money Market Services (MMS) survey:

Every two weeks from January 1983 to October 1984, MMS spoke by phone with an average of 30 curency traders or currency room economists at major international banks. Respondents were asked for theif expectations of the value of the pound, makk, Swiss franc and yen against the dollar in two weeks and three months time. From October 1984 to February 1986, MMS conducted its survey every week, asking for expectations one week and one month into the future (p. 4).

For normally distributed future spot rates, such ambiguity would not matter since mode and mean are equal; if the distributions are asymmetric, however,

\footnotetext{
10FrankeluFroot (1986), p. 4.
} 
mode and mean are unequal." Consequently, the respondents' interpretations become important, and changes in the median respondent, the identity of the responding institutions or their spokesman makes the interpretation of survey expectations even more problematic.

Since these are unavoidable properties of survey data, they cloud the interpretation of survey-based findings. The other two possible sources of the disparity between the findings - different data and different time periods - can be tested. For Fama's study, reestimation of the model will determine whether, over the latter period on the same data, his results still diverge from those of Frankel and Froot. Thus, in the next section, we reestimate Fama's model over a period including the 1981-85 pertod and use the same data source as Frankel and Froot."

\section{FAMA'S TEST FOR A VARIABLE RISK PREMIUM, AN EXTENSION}

Fama's 1984 test for a variable risk premium decomposes the forward premium $\left(\mathrm{F}_{1}-\mathrm{S}_{1}\right)$ into its two components: the expected change in the spot rate $\left[E\left(S_{1},-S_{4}\right)\right.$ and the risk premium $\left[P_{1}\right]$ as shown in equation 2. Fama then considers two regressions using the forward premium as the explanatory variable and each of the two components of the forward premium - the forward rate error, $\mathrm{F}_{i}-\mathrm{S}_{\mathrm{t}, \mathrm{t}}$ and the actual change in the spot rate, $S_{1:-}-S_{t}-$ as dependent variables:

(6)

$$
\mathrm{F}_{1}-\mathrm{S}_{1: 1}=\mathrm{a} 1+\mathrm{b} \mathbf{1}\left(\mathrm{F}_{1}-\mathrm{S}_{1}\right)+\mathbf{e} \mathbf{1}_{1}
$$

"That is, when distributions are not symmetric, the different statistics that survey respondents might interpret as "expectations" will be widely divergent. When distributions of future spot exchange rates are symmetric, the mean and mode (most likely future exchange rate) are the same. Also, the odd moments of a symmetric distribution are zero, so that skewness could not influence a survey respondert's answer. If distributions are asymmetric, however, the mean and mode will diverge and nonzero skewness (the third moment of the distribution) influence the risk premium and, hence, the survey response. For example, consider two alternative distributions for the DM one month in the future:

I. Symmefric Distribution (Wkelihood)

$\$ .667(10 \%), \$ .606(80 \%), \$ .545(70 \%)$.

11. Asymmetric Distribution (ikelihood)

$\$ .667(20 \%), \$ .606(80 \%)$

In each distribution, the mode is $\$ .606$, which is also the mean of I but, the mean of $I 1$ is $\$ .618$. Thus, the statistic that respondents report as their expected vatue matters for distribution II, but does not matter for distribution 1.

${ }^{12}$ Frankel and Foot (1986) use spot and forward exchange tate data from DRI, while Fama (1984) uses data from Harris Trust National Bank of Chicago. In the results reported in tables 1 and 2 , we use DAl data. and

$(7)$

$$
S_{1+1}-S_{t}=a 2+b 2\left(F_{t}-S_{t}\right)+e 2_{t}
$$

In these regression equations, b2 estimates the accuracy of the forward premium in predicting the actual change in the spot rate, whereas b1 reveals the risk premium component of the forward premium. Since the premium and forward rate errors may have nonzero covariance, the coefficients in (6) and (7) cannot be used directly to measure the proportion of variation due to risk and forecast errors, but the difference between them does provide some information,.$^{13}$

The difference between the two estimated coefficients, (b1 - b2), provides statistical evidence on the proportional importance of variation in the risk premium vs. variation in the rational future spot rate forecast error as sources of variation in the forward premium. Specifically, if $\mathrm{b} 1-\mathrm{b} 2$ is positive and statistically significant, most of the variation in forward premium is due to variation in the risk premium." Conversely, if $b 1-b 2$ is negative and statistically significant, most of the variation is due to variation in the expected change in the exchange rate. Finally, if b1 - b2 is not significant, it is not possible to draw any conclusions about the source of variation.

As shown in Fama (1984), p. 21, by assumption of rational expectations.

$$
\begin{aligned}
\mathbf{b} 1 & =\frac{\operatorname{cov}\left(F_{t}-S_{1: 1} F_{i}-S_{t}\right)}{\sigma^{2}\left(F_{t}-S_{t}\right)} \\
& =\frac{\sigma^{2}\left(P_{t}\right)+\operatorname{cov}\left(P_{: 1} E_{1}\left(S_{1: 1}-S_{1}\right)\right)}{\sigma^{2}\left(F_{t}-S_{t}\right)}
\end{aligned}
$$

and

$$
\begin{aligned}
& \mathrm{b} 2=\frac{\operatorname{cov}\left(S_{1: 1}-S_{1}, F_{1}-S_{1}\right)}{\sigma^{2}\left(F_{1}-S_{1}\right)} \\
& =\frac{\sigma^{2}\left(E_{i}\left(S_{1,1}-S_{1}\right)\right)+\operatorname{cov}\left(P_{n} E_{(}\left(S_{1 ;},-S_{1}\right)\right)}{a^{2}\left(F_{1}-S_{i}\right)}
\end{aligned}
$$

Since the covariance term appears in the b1 and b2 regression coefficients, neither bt nor b2 can be used by itself to assess the relative contribution of risk or forecast error to the forward premium; however, since they have a commor denominator, $\mathrm{r}^{2}(\mathrm{~F},-\mathrm{S})$, the difference between b1 and b2, which does not contain this term in the numerator, can be used to provide evidence about the proportional contribution or risk and forecast error.

$$
b^{t}+b_{2}=\frac{a^{2}\left(P_{1}\right)-\sigma^{2}\left(E_{i}\left(S_{t+i}-S_{i}\right)\right)}{\sigma^{2}\left(F_{i}-S_{1}\right)} .
$$

${ }^{14}$ The standard error of b1 - b2 is twice the common standard error of b1 and b2: Since (6) and (7) imply that $b_{1}+b_{2}=1$, by definition of the variance of $b_{1}-b_{2}$

$$
\begin{aligned}
\sigma\left(\hat{b}_{1}-\hat{b}_{2}\right) & =\left[E\left(\hat{b}_{1}-b_{1}-\left(\hat{b}_{2}-b_{2}\right)\right)^{2}\right]^{1 / 2} \\
& =\left[E\left(\hat{b}_{1}-b_{1}-\left(1-b_{1}\right)+\left(1-b_{1}\right)\right)^{2}\right]^{1 / 2} \\
& =2 \sigma\left(b_{1}\right) .
\end{aligned}
$$




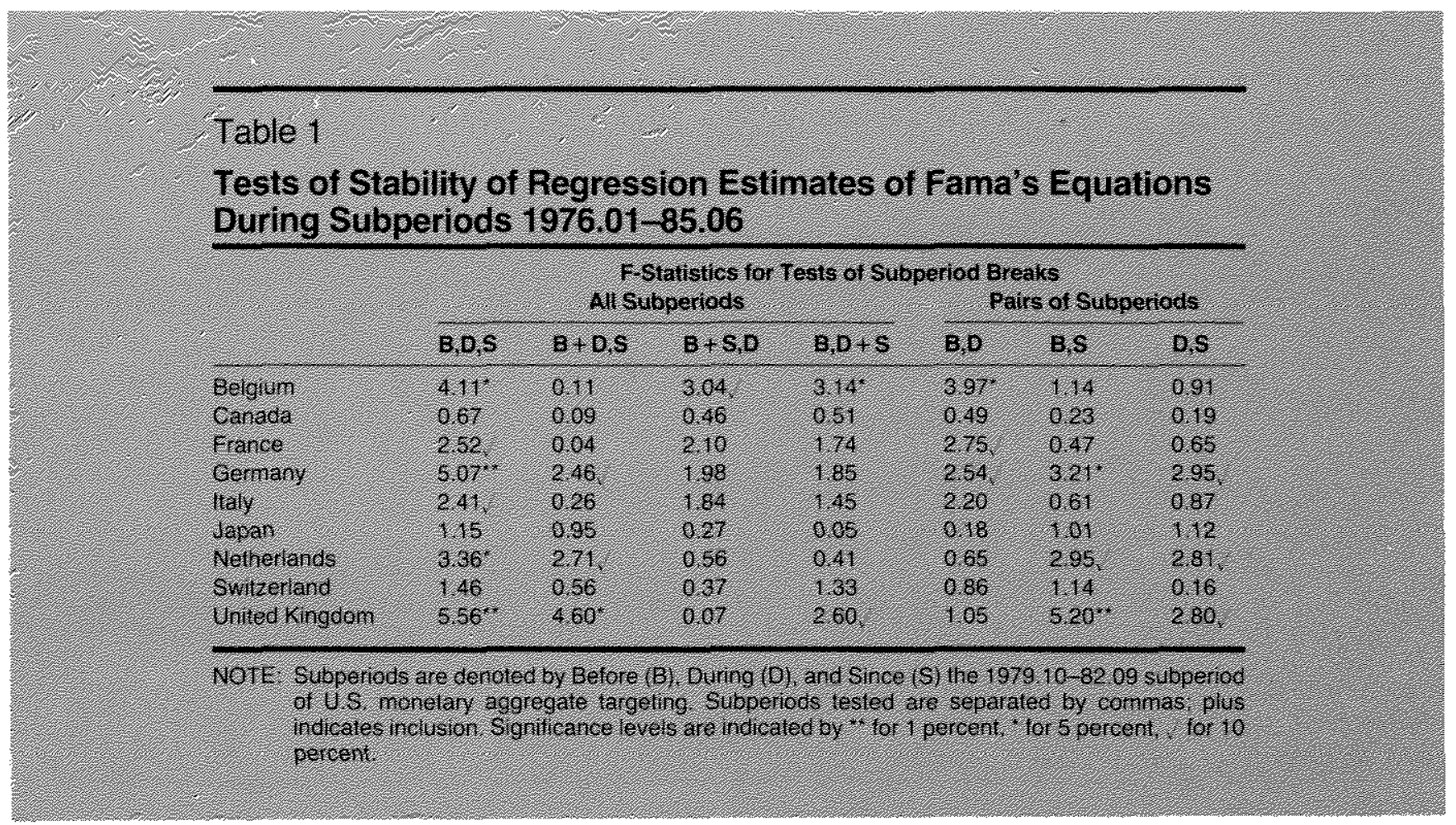

\section{Fama's Specification Estimated by Subperiods, 1976-85}

One possible reason that different sample periods (Fama, 1973-82; Frankel-Froot, 1981-85) yield different results is that the structure of markets may have changed during or between these periods. Economists have argued that the so-called peso problem makes the 1973-76 period difficult to interpret." Others have argued that the development of foreign exchange markets, leaming curve behavior of agents and the evolution of floating exchange rate policy are other reasons why subperiods may differ in structure." In particular, several authors have presented evidence that a change in the monetary regime in the United States during the last quarter of 1979 may have caused a structural change." Consequently, we have estimated Fama's model, equations 6 and 7 , over all combinations of the three subperiods of 1976.01-1985.06:

\footnotetext{
isThe peso problem reters to the devaluation of the Mexican peso which was anticipated throughout the 1973-76 period and which occurred in early 1976. More generally, it refers to any anticipated exogenous event that does not occut within the sample period. See Krasker (1979) and Isard (1987).

16ee lsard (†987).
}

${ }^{17}$ For example, see Ott and Veugelers (1986) and Frenkel (1986). before $(B)$, during (D) and since (S) the interval of monetary aggregate targeting, 1979.10-1982.09.'

F-statistics for tests of these structural breaks over the 1976-85 period against the null hypothesis of no breaks are reported in table 1 . These Chow tests are used to determine the proper estimation subperiods to be reported in table 2 . As the first column of table 1 indicates, Canada, France, Italy, Japan and Switzerland do not reject the fullmperiod structural stability hypothesis, and their regression estimates in table 2 are for the undivided full period, indicated by $\mathrm{B}+\mathrm{D}+\mathrm{S}$. Belgium, Germany, the Netherlands and the United Kingdom reject the null hypothesis at the $\mathbf{5}$ percent level or better, and their regression estimates are reported by the appropriate subperiods. ${ }^{19}$

Table 2 reports the regression estimates of $(6)$ and $(7)$ for the nine currencies whose structures were examined in table 1. Overall, the b1 - b2 test reported in the

13The later starting date also avoids the peso problem: see Krasker (1979).

: interestingly, the data for none of the countries supported the alternative hypothesis that the Before and Since subperiods were the same. Germany and Belgium provided evidence that all three periods were dissimilar, while the Netherlands and the United Kingdom indicated that the Before and During subperiods were similar but jointly different from the Since subperiod. 


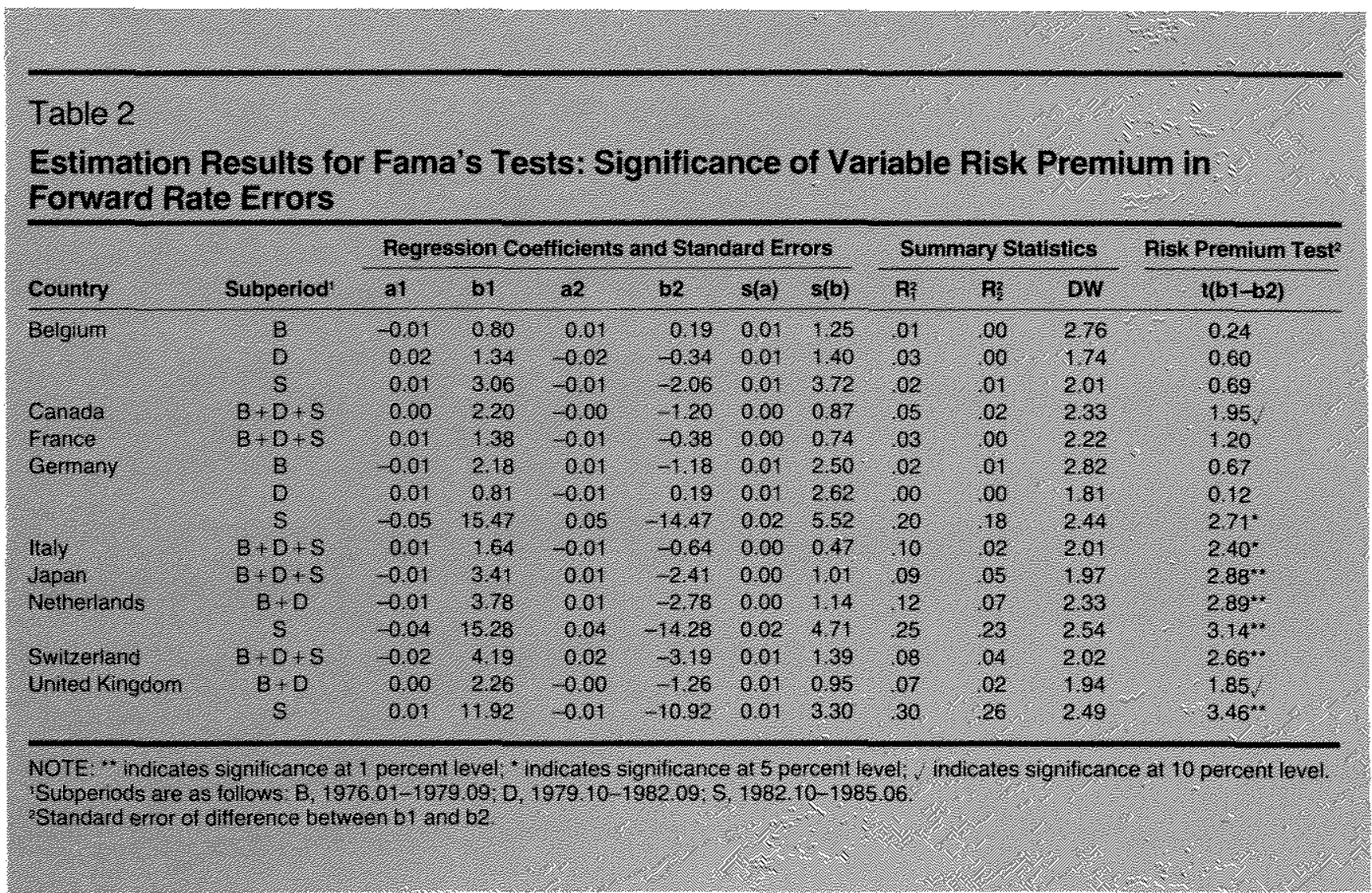

last column reasserts the relative importance of the risk premium that Fama found in his original tests. This result holds both for currencies that revealed structurally differentiated subperiods and for currencies that did not, that is, Canada, Italy, Japan and Switzerland. Of the nine currencies, only the Belgian franc and the french franc failed to support the statistically greater importance of the risk premium over the expected change in the exchange rate." The other results reported in table 2 indicate that the results are quantitatively similar to those reported by fama for the same curmencies over a shorter sample and different data set.

\section{CONCUUSTON}

Markets for foreign exchange are well-organized, high-volume interactions that encompass the trading activities of many competifive profit-seeking agents. That is, they appear similar in many functional as-

\footnotetext{
${ }^{29}$ But even for Belgium and France, the difference b1 - b2 was posi" tive so that forecast error variance was not greater than risk premia variance for any currency.
}

pects to other (domestic) financial markets so that the hypothesis of efficiency is plausible. Empirical tests, however, have rejected the joint hypothesis of market efficiency and no risk premium in the foreign exchange market. That is, while CIP holds, UIP does not.

Consequently, the role of the risk premium in foreign exchange markets often was not distinguishable from market inefficiency until Fama's (1984) analysis provided a test of its importance in the foreign exchange market. Frankel and Froot (1986) have provided survey-based evidence that also supports the existence of a risk premium but conflicts with Fama's assessment of the risk premium's economic impor tance. We have replicated Fama's study for an extended sample period and, although the results varied substantially by subperiods, found results that in general corroborate Fama's findings. What this impasse suggests is that the economic significance of the risk premium will not be resolved by tests of its existence, but may require direct modelling of the portfolio choice problem from which it arises. ${ }^{21}$

\footnotetext{
2For an application of portfolio choice theory to this problem, see Bomhoff and Koedijk (1987).
} 


\section{RERTRERCES}

Bilson, John F. O. "The 'Specutative Efficiency' Hypothesis," Journat of Business (July 1981), pp. 435-51.

Bomhoft, Eduard $J_{\text {. }}$ and Kees G. Koedijk. "Bilateral Exchange Rates and Risk Premia," Joumal of International Money and Finance, forthcoming.

Boothe, Paul, and David Longworth. "Foreign Exchange Market Efficiency Tests: Implications of Recent Empirical Findings," Journal of International Money and Finance (June 1986), pp. 135-52.

Clinton, Kevin. "Transactions Cost and Covered Interest Arbitrage: Theory and Evidence," mimeo (Bank of Canada, April 1987).

Cumby, Robert E., and Maurice Obstfeld. "A Note on Exchange-Rate Expectations and Nominal Interest Differentials: A Test of the Fisher Hypothesis," Journal of Finance (June 1981), pp. 697-703

"Intemational Interest Rate and Price Level Linkages under Flexible Exchange Rates: A Review of Recent Evidence, " in John F. O. Bilson and Richard C. Marston, eds., Exchange Rate Theory and Practice (University of Chicago Press, 1984), pp. 12151

Fama, Eugene F. "Efficient Capital Markets: A Review of Theory and Empirical Work," Journal of Finance (May 1970), pp. 383-417.

. "Forward and Spot Exchange Rates," Journal of Monetary Economics (November 1984), pp. 319-38.

Frankel, Jeffrey A., and Kenneth A. Froot. "Interpreting Tests of Forward Discount Bias Using Survey Data on Exchange Rate Expeciations," National Bureau of Economic Research Working Paper No. 1963 (June 1986).

"Using Survey Data to Test Standard Propositions Regarding Exchange Rate Expectations," American Economic Review (March 1987), pp. 133-53.

Frankel, Jeffrey A., and Richard Meese. "Are Exchange Rates Excessively Variable?" National Bureau of Economic Research Working Paper No. 2249 (May 1987).

Frenkel, Jacob A. "Flexible Exchange Rates, Prices and the Role of
'News': Lessons from the 1970s," Journal of Political Economy (Augus: 1981), pp. 665-705.

"Comments on Hodrick-Srivastava," Journal of international Money and Finance, Stupplement, Vol. 5 (March 1986), pp. $523-30$.

Hansen, Lars Peter, and Robert J. Hodrick. "Forward Exchange Rates as Optimal Predictors of Future Spot Rates: An Econometric Analysis, Journal of Political Economy (October 1980), pp. 829-53.

Hodrick, Robert J., and Sanjay Srivastava. "The Covariation of Rjsk Premiums and Expected Future Spot Exchange Rates," Joumal of International Money and Finance, Supplement, Vol. 5 (March 1986), pp. 5-21.

Isard, Peter. "Lessons from Empirical Models of Exchange Rates," IMF Staff Papers (March 1987), pp. 1-28.

Krasker, William S. "The 'Peso Problem' in Testing the Efficiency of Forward Exchange Markets," Journal of Monetary Economics (April 1980), pp. 269-76.

Levich, Richard M. "On the Efficiency of Markets for Foreigr Exchange," Rudiger Dornbusch and Jacob A. Frenkel, eds., International Economic Policy - Theory and Evidence (John Hopkins University Press, 1979), pp. 246-67.

"Empirical Studies of Exchange Rates: Price Behavior, Rate Determination and Market Efficiency." in Ronald W. Jones and Peter B. Kenen, eds., Handbook of Intemational Economics, Vol. 2 (Elsevier: North Holland, 1985), pp. 979-1040.

Meese. Richard A, and Kenneth Rogoff. "Empirical Exchange Rate Models of the Seventies: Do They Fit out of Sample?" Journal of Intemational Economics (February 1983), pp. 3-24.

Ott, Mack, and Paul T. W. M. Veugelers. "Forward Exchange Rates in Efficient Markets: The Effects of News and Changes in Monetary Policy Regimes," this Review (June/July 1986), pp. 5-15.

Robichek, Alexander A., and Mark R. Eaker. "Foreign Exchange Hedging and The Capital Asset Pricing Model, "Journal of Finance (Jure 1978), pp. 1011-18.

Sweeney, Richard J. "Beating the Foreign Exchange Market," Journal of Finance (March 1986), pp. 163-82. 